\title{
Social Reality as Legal Authenticity (Criticism of Bad Positive Laws in Legislation)
}

\author{
Yogi Prasetyo
}

Faculty of Law, Universitas Muhammadiyah Ponorogo, Indonesia, E-mail: yogiprasetyomadiun@gmail.com

Submitted: February 8, 2021; Reviewed: March 1, 2021; Accepted: March 14, 2021

Article Info

Abstract

Keywords:

Social reality, criticism, laws in legislation.

DOI:

10.25041/fiatjustisia.v15no3.2194
This study aims to explain social reality as the authenticity of Indonesian law and criticism of legal positivism in the legislation. This study using a literature study research method with a legal philosophy approach. Data obtained from the results of literature studies on several scientific works related to the theme of the problem. Data analysis was performed using descriptive, evaluative methods. The results of the research show that there is an incorrect understanding of the law in society. This is because the legal system used in Indonesia still refers to the legacy of the Dutch colonialists. Law is only understood as mere legislation. Apart from that, it is not considered law, such as social realities in people's lives. Laws must be written and issued by state institutions, not norms that arise from social life in society. The law's impact is dry from the social values of society so that the law is far from the sense of justice that is expected by the community. This study is expected to provide benefits to uphold the authentic Indonesian legal sovereignty that originates from the social realities of society. So that Indonesia is free from the bad influence of the legacy of the Dutch colonial legal system because the social reality of society is the original form of Indonesian law.

\section{A. Introduction}

In Indonesia, the law is understood as a legislation. Understanding law like this has become an absolute understanding in Indonesia. When people are asked what law is, the answer is legislation. Of course, this understanding cannot be justified without considering other legal elements. Structurally, the legislation takes precedence over other sources of law. This has an impact on its very dominant role in the national legal system. This understanding has 
placed legislation as the essential positive law, binding and compelling force on society. The rational logic closed in the positive legal system is considered to have more certainty value for law enforcement officials to implement legislation. ${ }^{1}$ So it is not surprising that the understanding of law in Indonesia, in this case, is very synonymous with legislation. ${ }^{2}$

Suppose the law is understood as mere legislation. In that case, the law is only writing containing orders, obedience, and sanctions issued by the state because the existence of law is closely related to the existence of a state. The state as the ruler has the authority to enforce the law by force against the people because the law is made in the ruler's interests. The state has the power to apply the law to the people it controls. In material terms, the law enforced by the state is positive law contained in the legislation. Other unwritten regulatory norms are not considered law or their position under the legislation. ${ }^{3}$ This point of view is certainly not under the realities of society because the law will never be able to write down society's social reality, which always changes with the times.

According to the understanding of legal positivism, formally, the actions of all state organs and society must be based on legislation. Thus the law has a higher degree of certainty. Law must be free from social elements because it has nothing to do with positive law. The entire implementation of the state system has been regulated in legislation. The state apparatus is a living figure who represents the law. Everything deemed necessary by the state has been regulated in legislation to measure its clarity and certainty. The most important thing is to achieve legal certainty, not a sense of community justice. This understanding resulted from narrowing the meaning of the law by legal positivism, which defines law as what is written in legislation. Besides that, it is not law. ${ }^{4}$ This perspective has negated legal facts in the form of social realities in society.

The domination of legal positivism in Indonesia results from the influence of the legacy of the Dutch colonial law, which took too long to control. The Indonesian legal system refers more to the civil law system implemented by the Dutch colonialists. Indonesia has not been able to escape the influence of the legal system inherited from the colonialists, even though the Indonesian state was already independent. It takes courage and a strong will to break away from Dutch colonial law and restore Indonesian law following the original law

\footnotetext{
${ }^{1}$ Thomas B. Nachbar, "The Rationality Of Rational Basis Review," Virginia Law Review 102, no. 7 (2016): 1627-28.

2 Sukris Sarmadi, "Membebaskan Positivisme Hukum Keranah Hukum Progresif (Studi Pembacaan Teks Hukum Bagi Penegak Hukum)," Jurnal Dinamika Hukum 12, no. 2 (2012): 341.

${ }^{3}$ Cynthia Nicoletti, "Writing The Social History Of Legal Doctrine," Buffalo Law Review 64 (2016): 121-40.

4 FX. Adji Samekto, "Menggugat Relasi Filsafat Positivisme Dengan Ajaran Hukum Doktrinal," Jurnal Dinamika Hukum 12, no. 1 (2012): 83. 
that originates from the social reality of society. The mainstream of legal positivism is not a law desired by the community because it does not arise from the social reality of the Indonesian people themselves, like using a foreign law that does not understand what is being done. As a result, the law feels far from what people want because the applicable law is different from their social reality in their daily lives. This situation is like the phenomenon of the application of the law put forward by Brian Z. Tamanaha. ${ }^{5}$

Social reality is a form of real law that lives and develops in society. Social reality is a legacy from our nation's ancestors that must be preserved as a sustainable living. Therefore, social reality deserves to be used as a source of law that has authenticity from within Indonesian society itself, not coercion by the Dutch colonialists. The formation of a good lawyer cannot be separated from the existing historical process because it will show the genuine authenticity of the law. This means that Indonesian law must be formed under the social realities that exist in society itself. Social reality is the original background as a source of law because it contains cultural values, customs, and religions that reflect the characteristics of the character of Indonesian society.

This study, using a literature study research method with a philosophy of law approach. The study of legal philosophy is a science that studies legal thought purely and deeply to its roots. The study of legal philosophy is also often referred to as the highest level of legal studies in the field of law. ${ }^{6}$ The study of legal philosophy has a wider area of study than normative law, which only examines the work of law in legislation. ${ }^{7}$ Research data are data from the results of literature studies related to the main themes of research problems inventoried for their suitability. In particular, data is related to the study of social reality as a living law in society and data related to the poor application of positive laws in force. Data analysis was performed using descriptive, evaluative methods to explain the aims and objectives of the study so that a good explanation of legal research can be obtained.

\section{B. Discussion}

\section{Misunderstanding The Law}

Legal positivism supported by the civil law system has stuck firmly in the domination of logical and rational reasoning. This is very important for police, prosecutors, judges, and state bureaucrats to support measurable work with definite standards. They are reluctant and do not want to get out of the

\footnotetext{
${ }^{5}$ Brian Z. Tamanaha, Beyond Formalist-Realist Divide (Princeton: University Press, 2010).

${ }^{6}$ Otje Salman, Filsafat Hukum (Perkembangan Dan Dinamika Masalah) (Bandung: PT Refika Aditama, 2010).

${ }^{7}$ Dewa Gede Sudik, "Fungsi Evaluatif Filsafat Hukum Terhadap Hukum Positif Indonesia," Jurnal Pandecta 8, no. 1 (2013): 35.
} 
confinement of the law in the form of legislation. ${ }^{8}$ The way of thinking of legal professionals closed logically in statutory conflicts cannot see the real legal reality in society. Law is understood as rule and logic, just like a one-way horse glass. The social dimension, which reflects people's lives, is not used in the formation of laws. As a result, the law in Indonesia is perceived as rigid and does not reflect the sense of justice in society. ${ }^{9}$

Legal law positivism in the form of legislation prioritizes lexical and grammatical interpretations as contained in the law. Understanding this law is forbidden to use the legal analogy equation because it is considered contrary to the law's legality (Nullum delictum nulla poena sine praevia lege poenali). The prohibition of this legal analogy is as contained in Article 1 paragraph (1) of the Criminal Code. The strong influence of legal positivism in the Indonesian legal system has been shown in every law enforcement apparatus handling cases. They must use statutory references in conducting legal proceedings. The main point in solving legal cases is to see how the written law in law regulates it. If not, then it is considered outside their authority. Even though there are regulations, but they are not by the community's sense of justice, then the legal process is still carried out. For example, Grandma Asyani was sentenced to one year in prison by judges for stealing teak branches from an Indonesian forest service agency. How much is the value of a wooden branch to make an old grandmother suffer the burden of being punished? However, the law does not see it as a sense of community justice, but the important thing is that laws and regulations can be implemented according to their provisions.

The pluralism of Indonesian society and the very diversity should make the law able to reduce legal positivism, especially laws related to social society. Social reality in community life can provide justice services to the community following the conditions in their environment. ${ }^{10} \mathrm{It}$ is not enough for a judge to just be a mouthpiece for the law, but he must open his eyes, ears, reason, and conscience wide open to form a law under the justice of society. Law is not sufficient with a textual perspective as written in the law because problems in society are increasingly complex. The use of a legal positivism point of view which is logically closed and has been linked to the state legal system, has made the Indonesian people accustomed to it and considers it as part of a legal culture that is acceptable for its application to become a common rule, even though in reality it has shown it to be a bad law.

Legal positivism in legislation does not matter whether the legal substance is fair or not, good or bad, contrary to morals, ethics, and religion or not. This

\footnotetext{
${ }^{8}$ Khudzaifah Dimyati, Dialektik Hukum: Karakteristik Dan Orientasi Pemikiran Hukum Berbasis Nilai Budaya Hukum Indonesia (Surakarta: Universitas Muhammadiay Press, 2008).

9 Satjipto Rahardjo, Sosiologi Hukum: Perkembangan Metode Dan Pemilihan Masalah (Surakarta: Muhammadiyah University Press, 2002).

${ }^{10}$ Shidarta, Karakteristik Penalaran Hukum Dalam Konteks Ke Indonesiaan (Bandung: CV Utomo, 2006). 
perspective has made the law look only in black and white to a problem, even though many legal problems are not sufficient to be handled textually, requiring a contextual interpretation. Like the Tukirin case, the farmer from Nganjuk City was accused by the prosecutor of stealing the patent rights for corn seeds. Tukirin was accused of stealing the mother seed. However, because it had been convincingly explained that the seeds were bought from a shop, the question led to planting corn. Tukirin was considered to have imitated growing corn, so Tukirin was found guilty by judges and sentenced. Many cases like the one above often occur in society, where positive law increases legal injustice for the community. Textual law enforcement can be considered too rigid and formalistic, ignoring the substantial aspects that are precisely the most important things in law. In such circumstances, legal positivism places itself in a difficult position to defend because its views on law are simplistic when dealing with problems in society.

This legal understanding can adversely affect the development of national law in Indonesia. Therefore, if the law is only seen as a mere system of norms, then legal development is also only oriented towards the development of a legal component related to the norm formation system, even though in reality, it is not enough to only involve components related to the norm system in applying the law as a norm. This problem makes the law dry, stiff, narrow, and petty. The impact can be in the form of difficulty making legal breakthroughs in solving problems because it is fixated on the sound of the text in the legislation. The law, in this case, feels very limited to what is written on paper. Do not look for other meanings beyond what has been written in the legislation.

Although the law aims to create order, it can also give rise to a disorder of law. ${ }^{11}$ This occurs because the law is understood in a narrow, informal, involutive, slow manner and cannot adapt and anticipate future developments. Evidence of the failure of legal positivism in legislation that cannot understand the fundamental law in society is the difficulty in providing justice that benefits society. The logical view of law closed in legal positivism tends to ignore the sense of justice in society. The law is also separated from the values of life that grow and develop in society, such as moral values, ethics, customs, and religions. All mistakes are only assessed by imprisonment, not feelings of regret, guilt, or shame, which are sanctions that have been used in everyday life so that the social dimension of law has disappeared from its duties as an institution that must return someone to society. Simultaneously, the law was created for the community, not the people, to fulfill legal interests.

Public trust in the law at this time began to disappear as a result of legal practice that was far from a sense of community justice. The authority of law enforcement officers has deteriorated so that the law in the form of legislation is deemed no longer able to provide concrete benefits to society. The law is

${ }^{11}$ Ahmad Ali, Menguak Teori Hukum Dan Teori Peradilan (Jakarta: Kencana, 2009). 
considered incapable of solving problems that occur in society fairly. The law is even powerless to face the violations and crimes that make justice increasingly difficult to achieve for the community. ${ }^{12}$ With their legal systems, law enforcement agencies have not been able to escape the bad influence of legal positivism, which positions laws and regulations as the main source of law that cannot be replaced, even though the laws in them are far from appropriate.

The law in Indonesia has experienced what is known as Indonesian ideological poverty, which has substantially lost the soul that should be preserved. This is because the institutions with the authority to form laws cannot see the reality of the law in society as real and genuine law in Indonesia. The implication of this situation is the increasing resistance to legal products that occur in society. There are many protests from elements of society about the new laws and regulations passed by the government. There was a rejection of legislation that was deemed contrary to a sense of justice. These laws include land, labor, mining, and other laws related to the community's life. There is no way of siding with the law to the community, so there is a tendency to harm the community.

\section{Social Reality as the Authenticity of Indonesian law}

Placing social reality as the domain of Indonesian law as original law is necessary to develop a better future legal politics. It should be emphasized that Indonesia must have the courage to determine what is best for this nation, including in building laws that have Indonesian characteristics. This situation is understandable because the law that comes from outside has its problematic characteristics. The Indonesian nation cannot be forced to follow the established law enforcement methods as in Western countries. The way of thinking of law should prioritize original legal thinking following the values of the reality of the life of Indonesian society. ${ }^{13}$ Social reality as the authenticity of Indonesian law is a set of shared life values obtained from society. In community life itself, of course, several rules are used to maintain the social system, such as Indonesian society, which already has laws.

The social reality of Indonesian society as the law is reflected in the principles contained in Pancasila, namely divine values, humanity, nationalism, democracy, and social justice. Even though each region in Indonesia is different, the values in social reality reflect the same Indonesian character. As in Javanese society, there is a philosophy of life in the form of a spirit of cooperation, "holopis kuntul baris", solving disputes wisely called "menang tanpo ngasorake", and democratic principles called "rembug deso".

\footnotetext{
12 Rabiatul Syariah, "Keterkaitan Budaya Hukum Dengan Pembangunan Hukum Nasional," Jurnal Equality 13, no. 1 (2008): 2.

${ }^{13}$ Khudzaifah Dimyati, Teorisasi Hukum: Studi Pemikiran Hukum Di Indonesia 1945-1990 (Yogyakarta: Genta Publishing, 2010). 
The social reality of the philosophy of life has been a local life system that has been adhered to in the way of life in Javanese society for a long time. The meaning contained in it has certainly gone through various assessments and adjustments, including the values of religious teachings, which are always sided by the side in the social life of society. ${ }^{14}$

Law as a political product in Indonesia has not yet displayed the true face of Indonesian law and only moves in the realm of formal and symbolic forms. The law is a social order whose origin must be able to protect the interests of the entire community. However, in reality, the idioms displayed only reflect the traditional form of the law, not the legal substance, which is much more important. According to the Indonesian legal figure, until now, he still has doubts about Indonesian legal science. There has not been any finding and development of an Indonesian legal paradigm based on the social realities of indigenous Indonesians as contained in the Pancasila ideology. The law in Indonesia is still the same as the formal laws in other countries. The value of Indonesian law is not visible; there is a tendency to take different directions because their interests are different. In legal positivism, the interests of power are more dominant than the interests of the people; what happens, in the end, the people become the disadvantaged parties in the law.

The problem now is how to dismantle a legal system that is only oriented to the form of law without paying attention to the essential things in law. Law in the final stage represents justice. However, the law will not be fair if it does not have an ideological framework of thought from the social reality of Indonesian society oriented towards its substance. In such a context, it is necessary to strengthen ideological thinking because it does not have a social basis in society as a place where law carries out its functions and roles in life. To understand the authenticity of Indonesian law, it can be seen from the social reality that develops in society. The various acculturations of life values are reflected in the content of the existing social institutions to regulate people's lives. Since a long time ago, Indonesian people have had their life system used to regulate their daily lives. The perspective of law by seeing law as a real social reality in society follows Gary Lawson's opinion in explaining the development of legal originality. ${ }^{15}$

The strong influence of legal positivism in legislation has been challenged by the emergence of legal thinking, which places legal studies no longer focusing on mere legislation, but on a broader legal context, namely law as a reality of social behavior. The perspective of law that lives and develops in Indonesia remains an alternative thought of law, and a more opposition-based undercurrent thought. Such a view observes the development of social studies

\footnotetext{
${ }^{14}$ Komisi Yudisial Republik Indonesia, Dialektik Pembarun Sistem Hukum Indonesia (Jakarta: Sekretaris Jenderal Komisi Yudisial Republik Indonesia, 2012).

15 Gary Lawson, "Reflections Of An Empirical Reader (Or: Could Fleming Be Right This Time)," Boston University Law Review 96 (2016): 1458-59.
} 
from the law, which talks about the increasing intellectual ascendancy of sociology. Social life in society can be a legal object that can carry out analysis and various tests of legal thinking concepts. With that, the law will be more extensive in its study and get updates that can keep up with developments. Therefore, there is criticism for legal positivism to return to simpler mechanisms and proof of law because rational reason often does not fully understand the law. ${ }^{16}$

In the process of judicial proceedings, the law is not only seen as a mere law but has a social aspect. Legal problems should also be able to be studied from how the legal reality in society. In legal analysis, it is necessary to depart from its identification as a social phenomenon in society. Thinking about the realities of law that exist in society will continue to move forward to dissect legal practices that are considered incompatible with existing realities. Law can not only be seen as a rational and abstract building, but the law has a more vibrant dimension, including what is seen as the reality of various complex social dimensions in society according to the times. The law does not remain silent without a positive reaction when it requires considerations that give rise to debate. The appearance of the law in the public space must prioritize the interests of the public at large, not the ruling group.

Social reality also has its place among legal thinkers in Indonesia, although its popularity is still inferior to legal positivism. It is possible to see it from the perspective of behavior and social culture so that an analysis is carried out against the law, which departs from identifying social phenomena. Legal figures have not widely uploaded social values that can be used to see the authenticity of Indonesian law. The social reality of society which is the original picture of Indonesian law, has mixed elements, such as customs, culture, and religion. It looks like some areas in Indonesia still hold the traditional traditions of their ancestors, although there are additions or variations of religious elements. All can be integrated into a single system of life in society. The acculturation of tradition and religion into the social life system of society is normal and runs harmoniously so that it shows the existence of good rules.

The legal profession in global life should refer to the social reality that exists in society which continues to develop from time to time, not deny it so that it is uprooted from the roots of community life. Therefore, legal professionals are an inseparable part of the life of the world community, which is always changing to develop with the times. Thus, legal development must be seen as a dialectical process of renewable intellectual struggles. It must be started by fundamentally changing the law as a social reality of a society practiced in everyday life to change legal thinking. The perspective of the law becomes more real. Understanding what has been practiced in everyday life;

\footnotetext{
16 Anthony J. Casey and Julia Simon-Kerr, "A Simple Theory Of Complex Valuation," Michigan Law Review 113 (2015): 1175-76. 
law is part of building national law. Transparency in improving the law is a necessity that cannot be postponed in the global era. Changing patterns of community life demand that the role of law is more agile.

Social reality as the authenticity of law is irrefutable evidence of the law that is desired by society. Its enforcement is a natural recognition in living systems. Without conveying loudly or with coercion, the people are aware of the existence of law, so such laws are genuine laws. If so, Indonesia should just formulate the social realities in society into the national legal system. The institution works according to the provisions adopted by the people in each region because all Indonesia is a country with various ethnic groups. The complexity of these differences becomes a challenge in shaping national law that reflects the authenticity of Indonesian law. This kind of situation is a supporter and can be a relatively vulnerable aspect of national unity. It is not easy to realize one law in a diversity of society. However, the fact is that Indonesian wants to or not have become part of this nation.

Based on social reality, which has an Indonesian ideology, the law will have its characteristics that reflect the authenticity of Indonesian law. According to the founders of the nation, the understanding of the authenticity of Indonesian law can be seen from the existence of customary law that is used by the community in their daily life. Customary law is a reflection of the legal reality in Indonesian society. Each region has its customary law, so it is not difficult for the Indonesian people to find and form their laws. The revolution against the Dutch colonialists was not merely a struggle to achieve independence. However, it was a joint movement of a social reality that any nation in the world could not avoid. So that with the end of the colonizers, Indonesia was faced with the problem of structuring life, which meant the formation of new laws and leaving the old laws inherited from the colonizers. Because the invader's inheritance law is not under the condition of Indonesian society, it has caused misery for the community.

Since ancient times, Indonesian people have had their laws, namely the realities of living and unwritten laws, which will continue to seek attention from the state following the development of the Indonesian legal system. Therefore, in the codification of law, there are new things that are not regulated in legislation. Social reality will function as law as there are no new laws for it. Because if this is not the case, there will be chaos due to the lawlessness. The reality of the law with all the events that occur can be a reference for law enforcers to become material for consideration or comparison in deciding cases. It is necessary to foster the Indonesian state order based on nationality, humanity, democracy, and social justice. This gives the leaders of this nation the task to rediscover the social values that exist in the social life of society as the main source of law, do not let the Indonesian people forget themselves and want to be like other nations by imitating the arrangements of their country. 
As an independent and sovereign country, Indonesia can determine its destiny according to its wishes. It can determine how the form and nature of the national legal system follow the social realities that develop in society. It is very important to guarantee the sovereignty of the law, not to follow the colonial law so that this independence can be fully felt, not independence. However, it feels like being colonized because the rules used still use the law of the colonial legacy. In maintaining the nation's dignity, Indonesia must have its legal system, which is extracted from the social civilization of the Indonesian people itself, not foreign laws that are enforced. There is no reason for Indonesia not to use the original law because the Indonesian state already has a natural and real source of law as a social reality in society.

According to the nation's founders, the Indonesian government has had original laws following the social realities of society in Indonesia, so there is no need to doubt its ability to overcome various existing problems. Social reality must be known, understood, and realized that all are rules that have been commonly used in everyday life so that their enforcement is natural. The existing regulations in social reality are not lower in degree than legislation. The evidence is still used in social life in society. All elements of the nation must respect the social reality that has become the institution of life by making it the primary source of law. Indonesian people had their rules for a long time before Dutch colonialism came. However, the understanding of the legal reality cannot be fully understood as law by the Indonesian people itself as the primary law which should be a reference in carrying out all activities.

Social reality as a source of law must be studied and discovered. Therefore there is no need to blame historical processes that have occurred. However, what must be done is to have the courage to improve yourself by walking on the right path, namely Indonesian law, not a foreign legal path with no known direction and goal. Reflection on legal reality is making significant efforts towards legal thinking and orientation, emphasizing the substantive manifestation of social values in society as the main source of law. According to the nation's founders, social realities such as in customary law can be extracted from the socio-cultural values that exist in society. This is more important and adequate to develop legal thinking to receive the same treatment as modern law developed in other countries. Social reality as a law that comes from the community can also function as control and local wisdom for the whole community to maintain a social life. Seeing law as a real empirical reality in society, according to Aditya Bamzai, can be done by conducting a traditional historical analysis of local customary laws that apply in people's lives. ${ }^{17}$

Social reality as the authenticity of law is a known, recognized, and respected rule but can affect all systems of life that exist in society. Social

\footnotetext{
${ }^{17}$ Aditya Bamzai, "The Origins of Judicial Deference to Executive Interpretation," The Yale Law Journal 126, no. 4 (2017): 908-1241. 
reality has strong ties in forming real laws that live and develop in society. The binding power of law based on social fact is evident from daily life in society. They have indirectly used the law in regulating their lives. Therefore, strict legal principles are needed, such as determining the rights and obligations of citizens and with sanctions if anyone violates them. Also, orders and prohibitions are usually included in the arrangement of life together in various activities, as contained in customary law in Indonesia. The state only regulates general policies in adopting social reality because technically relevant matters have become the working area of law in society. The most important thing is the existence of policies and legal recognition from the state.

As the originator of legal authenticity, social reality contains a life view and religious beliefs. This is reflected in the teachings of Islam, which are generally embraced by the Indonesian people and have become part of a system that is inseparable from the social realities of society. Elements containing social values merge into a unified legal system that is adhered to by the community and becomes a routine of life that is practiced daily. Such as "selamatan" and "kenduri" activities in Javanese society. These activities contain broad social values in interpreting social life. This activity has been elaborated by providing additional prayers that come from Islamic law. These activities become guidelines that are upheld by the community, not only because the spiritual atmosphere is related to the element of belief alone but also because social elements are considered positive in the development of social life. There is a sense of legal acceptance from society naturally without an element of coercion. This is exactly what the law expects.

The same activity can also be seen in the community of Kampung Naga in Tasikmalaya. Social traditions inherited from their ancestors can go hand in hand with the teachings of Islam in people's lives. In the tradition of the community, it is seen that the wall must be made of wood or bamboo, so this can also be seen in the building of the walls in the mosque, which are made of wood or bamboo as well. This tradition shows the acculturation of the community's social culture with the teachings of Islam in achieving a better life goal. The social reality that shows the authenticity of law as in the example above can be seen from community life activities, which become common law. The influence of religion in life becomes a reality that cannot be hidden. The synergy of the various elements that form social reality as law can be seen from the strong influence of one element on another.

Religious teachings are a social system that grows and develops in society as a symbol of their identity. This is an authentic reality of law that comes from the social reality of society, not a law made with ideological imaginations far from the reality of people's lives. Religion has an important influence on the social life of society in all fields. This is like the situation in Indonesian society, where religion has become a unitary system containing values that are the capital to build the nation, including in law. In a civilized 
society, all of their behavior contains good values that cannot be separated from the influence of religion. Religion has also become a social reality that forms an element of law-forming in Indonesian society. That is the importance of religion in influencing people's lives. ${ }^{18}$

According to UNESCO, the social system results from human work, which involves all aspects of human life, including belief and spirituality. ${ }^{19}$ Therefore, to see the true authenticity of Indonesian law, a form of community attitudes and behavior will be obtained, which contains local wisdom values, customs, views of life, and values contained in religious teachings. Like the teachings of Islam in Indonesia, it has become a view of life together in society's socio-cultural system, providing an authentic picture of Indonesian law. These become social realities that can represent original Indonesian law because the law is part of social life that cannot be separated from religion's influence. The broad nature of religious studies covering almost all aspects of life has contributed to shaping laws derived from social reality.

Trust and spirituality in the social life of the Indonesian people are very strong. The condition of the people who still often carry out activities related to nature and the environment makes the nuances of magic with supernatural powers still felt. The pattern of community life that still uses traditional methods can lead to a strong spiritual influence. Belief in things that have supernatural powers creates an influence that is still preserved in people's lives in Indonesia. In a broader context, Indonesian society basically cannot be separated from the spiritual element. Thus, it depends on the ability of the leaders of this country to understand and make the values contained in social reality the main source of law that is born, grows, and develops in society.

Understanding religious values by the leaders of this country is essential to form laws that reflect the authenticity of law in Indonesia. All forms of attitudes and behavior of society can be studied religiously. This means that religion is not just sharia written in the holy book but must be understood as a complete existing form, where its true meaning can be captured from symbols in people's lives. The social life that describes the legal reality of Indonesian society can be understood as religious values following the context and purpose. All the behaviors that exist in social interactions seem to be interrelated with religious elements. The adjustment of community traditions with the values of religious teachings results in an activity that can accommodate different elements into one that supports and completes each other.

Social reality as the authenticity of Indonesian law can become government policy in shaping better national law. Social values that live and

\footnotetext{
${ }^{18}$ Khadiq, “Agama Sebagai Modal Pebangunan Masyarakat," Jurnal Aplikasi Ilmu Agama 6, no. 2 (2005): 124.

${ }^{19}$ Amri Marzali, "Memajukan Kebudayaan Nasional Indonesia," Jurnal Humniora 36, no. 3 (2014): 262. 
develop in society are understood together as an institution that can be used as a source of Indonesian national law. The existing legal system in the area can show the mechanism of a set of functions and roles interrelated with one another in a continuous legal process from the past, present, and future by following human behavior in life in society. The social values usually bind the legal system in society that a particular society wants to apply, reflected in various forms of attitudes and behavior in everyday life. So there is a strong enough reason for the Indonesian people to take social reality as the source of law.

\section{Conclusion}

There is an inaccurate understanding of what law is in Indonesia. In general, the law is better understood as written legislation issued by the state. Apart from that, it is not considered law, as the values of life in society's social reality. This happens because the legal system inherited from the colonialists has influenced Indonesian law. Several problems arising from the legal system, which tend to take legal positivism, have often occurred. The tendency to apply the law under what is contained in legislation often clashes with the sense of justice in society. The legal system that is closed in legislation does not open space for the entry of social realities in society as a basis for consideration to participate in solving legal problems. So that the law is carried out as written in the text of the legislation. At the same time, the social reality of society is a real picture of law that can be used as a basis for forming a good law following the actual situation.

\section{References}

Ali, Ahmad. Menguak Teori Hukum Dan Teori Peradilan. Jakarta: Kencana, 2009.

Bamzai, Aditya. "The Origins of Judicial Deference to Executive Interpretation." The Yale Law Journal 126, no. 4 (2017): 908-1241.

Casey, Anthony J., and Julia Simon-Kerr. "A Simple Theory Of Complex Valuation." Michigan Law Review 113 (2015): 1175-76.

Dimyati, Khudzaifah. Dialektik Hukum: Karakteristik Dan Orientasi Pemikiran Hukum Berbasis Nilai Budaya Hukum Indonesia. Surakarta: Universitas Muhammadiay Press, 2008.

- Teorisasi Hukum: Studi Pemikiran Hukum Di Indonesia 1945-1990. Yogyakarta: Genta Publishing, 2010.

Indonesia, Komisi Yudisial Republik. Dialektik Pembarun Sistem Hukum Indonesia. Jakarta: Sekretaris Jenderal Komisi Yudisial Republik Indonesia, 2012.

Khadiq. "Agama Sebagai Modal Pebangunan Masyarakat." Jurnal Aplikasi Ilmu Agama 6, no. 2 (2005): 124.

Lawson, Gary. "Reflections Of An Empirical Reader (Or: Could Fleming Be 
Right This Time)." Boston University Law Review 96 (2016): 1458-59. Marzali, Amri. "Memajukan Kebudayaan Nasional Indonesia." Jurnal Humniora 36, no. 3 (2014): 262.

Nachbar, Thomas B. "The Rationality Of Rational Basis Review." Virginia Law Review 102, no. 7 (2016): 1627-28.

Nicoletti, Cynthia. "Writing The Social History Of Legal Doctrine." Buffalo Law Review 64 (2016): 121-40.

Rahardjo, Satjipto. Sosiologi Hukum: Perkembangan Metode Dan Pemilihan Masalah. Surakarta: Muhammadiyah University Press, 2002.

Salman, Otje. Filsafat Hukum (Perkembangan Dan Dinamika Masalah). Bandung: PT Refika Aditama, 2010.

Samekto, FX. Adji. "Menggugat Relasi Filsafat Positivisme Dengan Ajaran Hukum Doktrinal." Jurnal Dinamika Hukum 12, no. 1 (2012): 83.

Sarmadi, Sukris. "Membebaskan Positivisme Hukum Keranah Hukum Progresif (Studi Pembacaan Teks Hukum Bagi Penegak Hukum)." Jurnal Dinamika Hukum 12, no. 2 (2012): 341.

Shidarta. Karakteristik Penalaran Hukum Dalam Konteks Ke Indonesiaan. Bandung: CV Utomo, 2006.

Sudik, Dewa Gede. "Fungsi Evaluatif Filsafat Hukum Terhadap Hukum Positif Indonesia." Jurnal Pandecta 8, no. 1 (2013): 35.

Syariah, Rabiatul. "Keterkaitan Budaya Hukum Dengan Pembangunan Hukum Nasional." Jurnal Equality 13, no. 1 (2008): 2.

Tamanaha, Brian Z. Beyond Formalist-Realist Divide. Princeton: University Press, 2010. 